ORIGINAL ARTICLE

\title{
Vitamin E and Focal Adhesion Kinase Inhibitor Y15 Enhances the Cytotoxic Effects of Cisplatin plus Paclitaxel in Platinum-resistant Ovarian Cancer Cells
}

\author{
M Reboe ${ }^{1}$, A Levy ${ }^{1}$, D Sivanesan ${ }^{2}$, A Rathinavelu ${ }^{2}$
}

\begin{abstract}
Objectives: The high drug-resistance associated with cisplatin and paclitaxel has complicated the treatment of ovarian cancer. This resistance has been linked to over-expression of focal adhesion kinase (FAK). More recently, a therapeutic platform for vitamin E was established in cancers and therefore, the present study assessed the cytotoxic effects of the FAK inhibitor 1 , 2, 4, 5-Benzenetetramine tetrahydrochloride (Y15) or vitamin E (alpha tocopherol succinate) $V E S)$ in combination with cisplatin and paclitaxel in a platinum-resistant ovarian cancer cell line.

Method: Platinum-resistant OVCAR-3 cells were treated with varying concentrations of Y15 or vitamin $E$ in combination with cisplatin plus paclitaxel over a 24-hour period in triplicate. Control cells were treated with media only. The cytotoxic profile of each treatment was determined using the automated Trypan blue assay and DNA fragmentation assay was performed to evaluate the mechanism of induced cell death.

Results: Dose dependent and statistically significant cytotoxic effects were seen with Y15 and vitamin E only when compared to controls with IC 50 values of $80 \mu M(\mathrm{p}<0.015)$ and 250 $\mu M(\mathrm{p}<0.02)$, respectively. Both Y15 and vitamin E $(24 \%$ and $27.16 \%)$ significantly increased the percentage cell death induced by cisplatin plus paclitaxel when given in combination. Cell death by apoptosis was confirmed from observed fragmented DNA in all Y15 and vitamin E treatment groups.

Conclusion: Vitamin E and Y15 significantly enhanced the cytotoxic activity of cisplatin and paclitaxel in OVCAR-3 cells.
\end{abstract}

Keywords: Platinum-resistant ovarian cancer, vitamin E, Y15

\section{La Vitamina E y el Inhibidor Y15 de la Quinasa de Adhesión Focal Mejoran los Efectos Citotóxicos del Cisplatino Combinado con Paclitaxel en las Células de Cáncer Ováricas Resistentes al Platino}

M Reboe ${ }^{1}$, A Levy $^{1}$, D Sivanesan ${ }^{2}$, A Rathinavelu $^{2}$

\begin{abstract}
RESUMEN
Objetivos: La alta resistencia a los medicamentos asociada con el cisplatino y el paclitaxel ha complicado el tratamiento del cáncer ovárico. Esta resistencia ha estado vinculada con la
\end{abstract}

From: ${ }^{1}$ Department of Basic Medical Sciences, Section of Pharmacology, The University of the West Indies, Kingston 7, Jamaica, West Indies and ${ }^{2}$ Rumbaugh Goodwin Institute for Cancer Research, Nova Southeastern University, $1850 \mathrm{NW} 69^{\text {th }}$ Avenue Suite 5 Plantation, FL 33313 USA.
Correspondence: Dr M Reboe, Department of Basic Medical Sciences, Section of Pharmacology, The University of the West Indies, Kingston 7, Jamaica, West Indies. Email:siva_655@yahoo. co.in 
sobreexpresión de la quinasa de adhesión focal (FAK, siglas en inglés). Más recientemente, se estableció una plataforma terapéutica para la vitamina E en cánceres y, por ende, el presente estudio evaluó los efectos citotóxicos del inhibidor de la FAK 1, 2, 4, 5-Bencenotetramina tetrahidrocloruro (Y15) o vitamina $E$ (alfa tocoferol succinato/VES) en combinación con cisplatino y paclitaxel en una línea de células de cáncer ovárico resistentes al platino.

Método: Las células OVCAR-3 resistentes al platino fueron tratadas con concentraciones variables de Y15 o vitamina E en combinación con cisplatino y paclitaxel durante un periodo de 24 horas por triplicado. Las células de control se trataron con medios sólo. El perfil citotóxico de cada tratamiento fue determinado usando el ensayo automatizado de tripán azul, y el ensayo de fragmentación de ADN fue realizado para evaluar el mecanismo de la muerte celular inducida.

Resultados: Los efectos citotóxicos dependientes de la dosis y estadísticamente significativos se observaron con Y15 y la vitamina E sólo cuando se compararon con los controles con valores de IC 50 de $80 \mu M(\mathrm{p}<0.015)$ y $250 \mu M(\mathrm{p}<0.02)$, respectivamente. Tanto Y15 como la vitamina E (24\% y 27.16\%) aumentaron significativamente el porcentaje de muerte celular inducida por el cisplatino con el paclitaxel cuando se administraron en combinación. La muerte celular por apoptosis se confirmó a partir de la observación de ADN fragmentado en todos los grupos sometidos a tratamiento con Y15 y vitamina E.

Conclusión: La vitamina E y Y15 mejoraron perceptiblemente la actividad citotóxica del cisplatino y el paclitaxel en las células OVCAR-3.

Palabras clave: Cáncer ovárico resistente al platino, vitamina E, Y15

West Indian Med J 2017; 66 (6): 669

\section{INTRODUCTION}

Ovarian cancer is the $7^{\text {th }}$ most common cause of cancer-related death in women worldwide (1). Debulking surgery followed by cisplatin and paclitaxel chemotherapy is a common treatment approach in advanced stage ovarian cancer. Approximately, $70 \%$ of patients with advanced stages of this disease, however, experience recurrence due to development drug-resistance within 12 to 18 months of disease remission (2).

The over-expression of the tyrosine kinase FAK is well-established in ovarian cancers (3-5) and has been recently linked to both taxane and platinum-resistance. Focal adhesion kinase is a $125-\mathrm{kDa}$ non-receptor tyrosine kinase that localizes at focal adhesion sites and is activated by intergrin signalling (5). Activation of the Y397 site triggers FAK catalytic activity (3) resulting in cell spreading, survival, migration, proliferation and angiogenesis. In ovarian cancers, FAK up-regulates the YB-1 transcription factor leading to increased CD44 expression which results in resistance to paclitaxel (6). Similarly FAK inhibition increases sensitivity to cisplatin in platinum-resistant ovarian cancer cells (7). Vitamin E (alpha tocopherol succinate) has demonstrated cytotoxic activity in multiple cancer cell lines
(8-10) and improved cisplatin-mediated cytotoxicity in platinum sensitive ovarian cancer cells through caspase activation (11).

Based on these lines of evidence, we utilized the FAK inhibitor Y15 which targets the Y397 activation site (12) to evaluate the combined effect of the FAK inhibition with vitamin $\mathrm{E}$, cisplatin and paclitaxel in a platinum-resistant ovarian cancer cell line (OVCAR-3). Our studies pivoted on evaluating the significance of FAK inhibition in platinum-resistant ovarian cancer and its potential to improve sensitivity to vitamin E, cisplatin and paclitaxel.

\section{MATERIAL AND METHODS}

\section{Cell culture}

The platinum-resistant ovarian cancer cell line, OVCAR-3, was obtained from the American Type Culture Collection (ATCC) and maintained in $80 \%$ RPMI-1640 medium supplemented with 20\% fetal bovine serum and $1 \%$ penicillin/streptomycin antibiotics. Cells were propagated as adherent monolayers and maintained in a humidified incubator of $5 \% \mathrm{CO}_{2}$ and $37{ }^{\circ} \mathrm{C}$. Cells were sub-cultured at approximately, $80 \%$ confluence and harvested for the various studies after 
brief trypsinization. Cell viability by Trypan blue assay was $>90 \%$.

\section{Dose response curves and combination treatments}

OVCAR-3 cells were plated at a density of $1 \times 10^{6}$ cells and treated for 24 hours at various concentrations of VES, Y15, cisplatin and paclitaxel obtained from Sigma Aldrich, United States of America. Vitamin E succinate was dissolved in dimethyl sulfoxide (DMSO) and added to the cells at final concentrations of $40 \mu \mathrm{M}, 80 \mu \mathrm{M}, 100$ $\mu \mathrm{M}, 200 \mu \mathrm{M}$ and $250 \mu \mathrm{M}$. The 1,2, 4, 5-Benzenetetramine tetrahydrochloride was dissolved in sterile tap water and added to the cells at final concentrations of $10 \mu \mathrm{M}, 15$ $\mu \mathrm{M}, 30 \mu \mathrm{M}$ and $100 \mu \mathrm{M}$. Dimethyl sulfoxide and media only treated cells were used as control. For combination treatments, VES $(250 \mu \mathrm{M})$ and Y15 $(80 \mu \mathrm{M})$ were used in combination with cisplatin and paclitaxel which were diluted in medium to the required final concentrations of $26 \mu \mathrm{M}$ and $1.5 \mathrm{nM}$, respectively. All treatment protocols were conducted in triplicate.

\section{Trypan blue cytotoxicity assay}

Following 24 hours treatment periods, cells were harvested and Trypan blue assay was conducted using a one to one ratio $(1: 1)$ of a $0.4 \%$ trypan blue solution. A BioRad TC10 automated cell counter was used to determine the number of viable cells.

\section{DNA fragmentation}

DNA fragmentation patterns were examined by electrophoresis of extracted genomic DNA from treated OVCAR-3 cells. Cells were incubated with the different combination treatments of VES $(250 \mu \mathrm{M}), \mathrm{Y} 15(80 \mu \mathrm{M})$, cisplatin $(26 \mu \mathrm{M})$ and paclitaxel $(1.5 \mathrm{nM})$ for 24 hours. Cells were re-suspended in $200 \mu 1$ of phosphate-buffered saline (PBS) supplemented with $20 \mu \mathrm{l}$ of proteinase K. The DNA was extracted using the Qiagen DNeasy Kit following the manufacturer's protocol. The samples were subjected to electrophoresis at $80 \mathrm{~V}$ for two hours in $1.5 \%$ agarose gel containing $5 \mu 1$ of ethidium bromide. DNA fragmentation patterns were visualized using UVP image analyser.

\section{Statistical analysis}

All experiments were performed in triplicate and data are presented as means \pm SEM. Student's $t$-test (SPSS software version 20) was used for analysis of the difference between treatment and the control groups and a $p$-value $<0.05$ considered statistically significant.

\section{RESULTS}

\section{Cytotoxicity assays}

Using the Trypan blue assay, the cytotoxic effects of VES and Y 15 on OVCAR-3 cells were evaluated. Both VES $(p<0.022)$ and Y15 $(p<0.015)$ significantly reduced cell viability in a dose dependent manner when compared to controls. Linear regression analysis determined the IC50 values of VES and Y15 to be $250 \mu \mathrm{M}$ and 80 $\mu \mathrm{M}$, respectively (Figs. 1a, 1b).

For combination treatments, VES $(250 \mu \mathrm{M})$ plus cisplatin $(26 \mu \mathrm{M})$ plus paclitaxel $(1.5 \mathrm{nM})$ displayed significant cytotoxic effects in OVCAR-3. Results showed that VES significantly enhanced the cytotoxic effects of cisplatin plus paclitaxel by $24 \%$ as this triple combination resulted in $59.11 \%$ cytotoxicity $(p<0001)$ in comparison to cisplatin plus paclitaxel only which produced $35.11 \%$ cytotoxicity $(p<0.00038)$ and VES only which produced $31 \%(p<0.0005)$ cytotoxicity (Fig. $2 \mathrm{a})$.

Similar results were recorded when Y15 was combined with cisplatin plus paclitaxel. OVCAR-3 cells treated with Y15 only, cisplatin plus paclitaxel or Y15 plus cisplatin plus paclitaxel all demonstrated significantly higher cytotoxic effects when compared against the control $(p<0.02)$. The Y15 plus cisplatin plus paclitaxel combination produced a $62.27 \%(p<0.00004)$ cytotoxic effect which was significantly higher than the cisplatin plus paclitaxel combination which produced a $35.11 \%(p<0.0005)$ cytotoxic effect. The Y15 plus cisplatin plus paclitaxel combination also produced a significantly ( $p=0.002)$ higher cytotoxic effect when

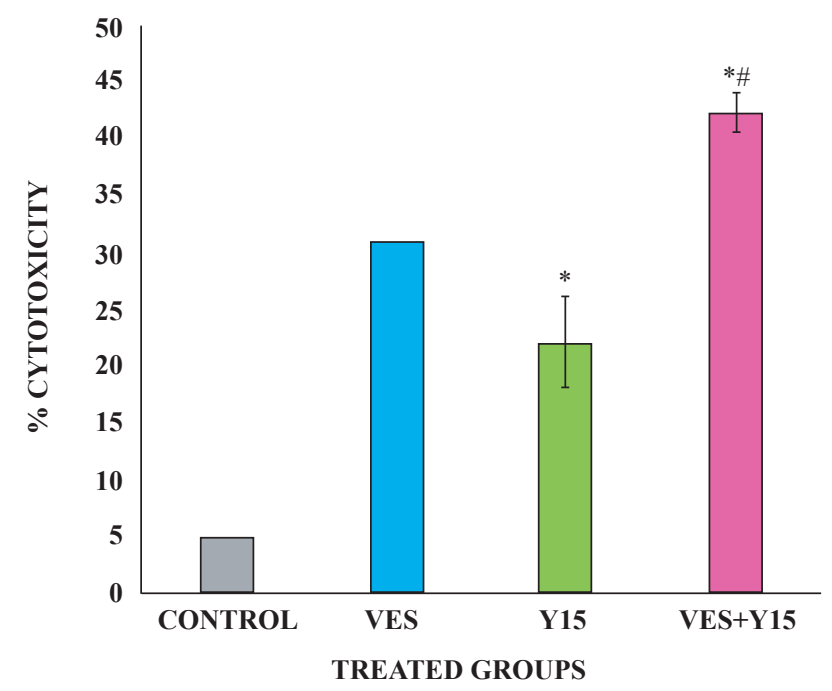

Fig. 1: Cytotoxic effect of Y15 $(80 \mu \mathrm{M})+$ VES $(250 \mu \mathrm{M})$ in OVCAR-3 cells with control sample at 24 hours. Data are representative of trials performed in triplicate \pm SEM. Asterisks $\left(^{*}\right.$ ) represent $p=0.05$ compared to the control group and number sign (\#) represents $p<$ 0.05 as compared to vitamin E succinate only and Y15 only. 
compared to the Y15 only treatment. Therefore, the cytotoxic actions of cisplatin and paclitaxel were enhanced by VES and Y15 in OVCAR-3 cells (Fig 2b).

We also, examined the combined treatment of VES plus Y15 (Fig. 2c). Analysis of VES plus Y15 against VES revealed $11.4 \%$ difference in percentage cytotoxicity $(p<0.02)$ moreover VES plus Y15 produced a

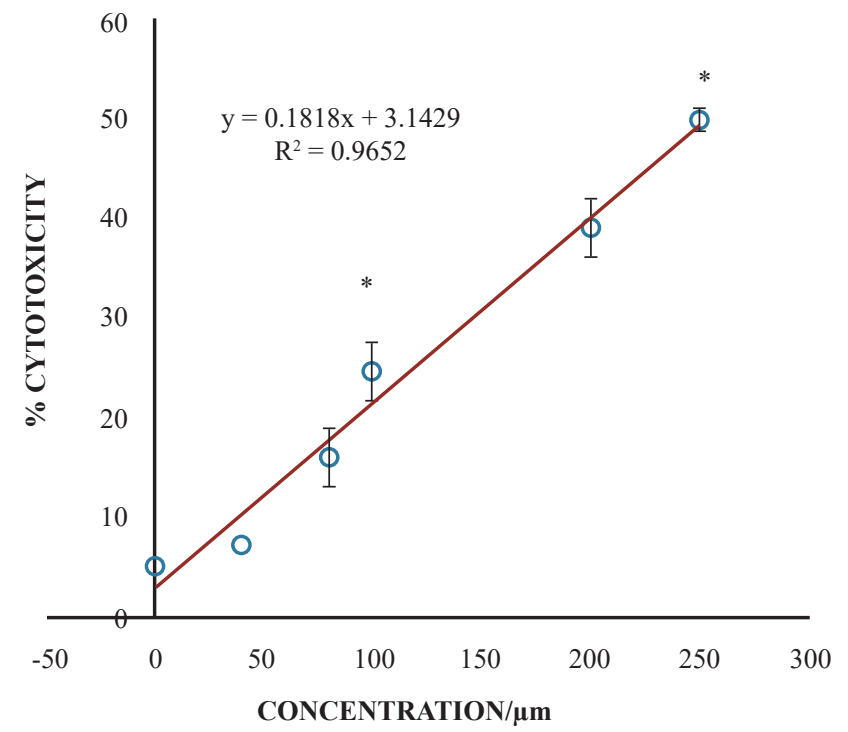

Fig. 1a: OVCAR-3 cells were incubated with vitamin E succinate $(40 \mu \mathrm{M}$, $80 \mu \mathrm{M}, 100 \mu \mathrm{M}, 250 \mu \mathrm{M})$ for 24-hour. Data is presented as the mean \pm SEM from triplicate experiments. Vitamin E succinate produced a significant and dose dependent reduction in cell viability with an estimated IC50 value of $250 \mu \mathrm{M}$. Asterisks represent values significantly different form dimethylsulfoxide controls $* p=0.020$.

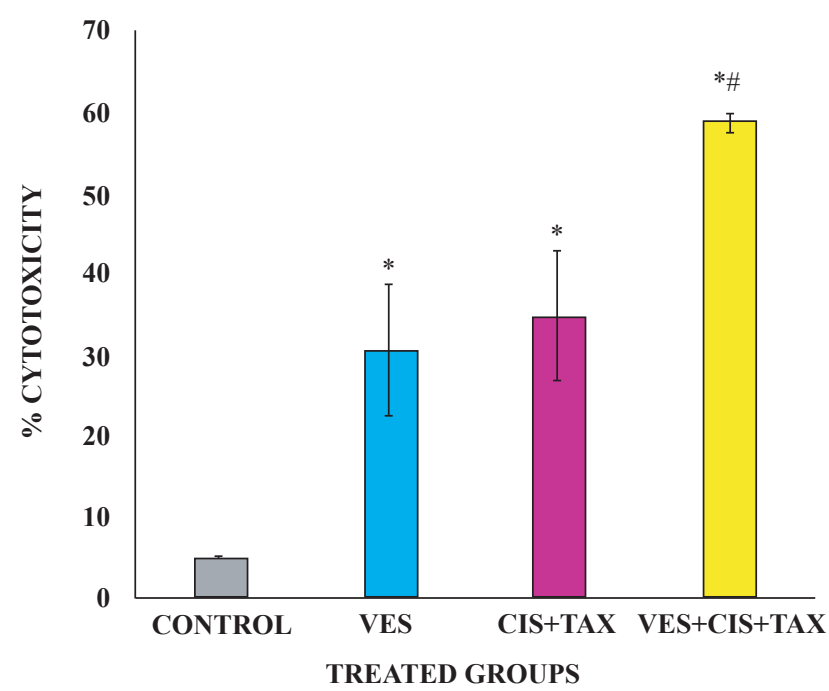

Fig. 2a: Cytotoxic effect of Vitamin E succinate $(250 \mu \mathrm{M})$ only, cisplatin $(26 \mu \mathrm{M})$ plus paclitaxel $(1.5 \mathrm{nM})$ and Vitamin E succinate plus cisplatin plus paclitaxel treated OVCAR-3 cells with control sample at 24 hours. Data are representative of trials performed in triplicate \pm SEM. Asterisks $(*)$ represent $p<0.005$ compared to the control and number sign (\#) represents $p<0.05$ as compared to cisplatin plus paclitaxel $(p<0.05)$. two-fold increase in cytotoxicity when compared to Y15 only $(p=0.05)$.

\section{DNA fragmentation assay}

To evaluate the involvement of apoptosis in the cytotoxic effects of VES and Y15; we assessed DNA fragmentation patterns in response to 24-hour exposure

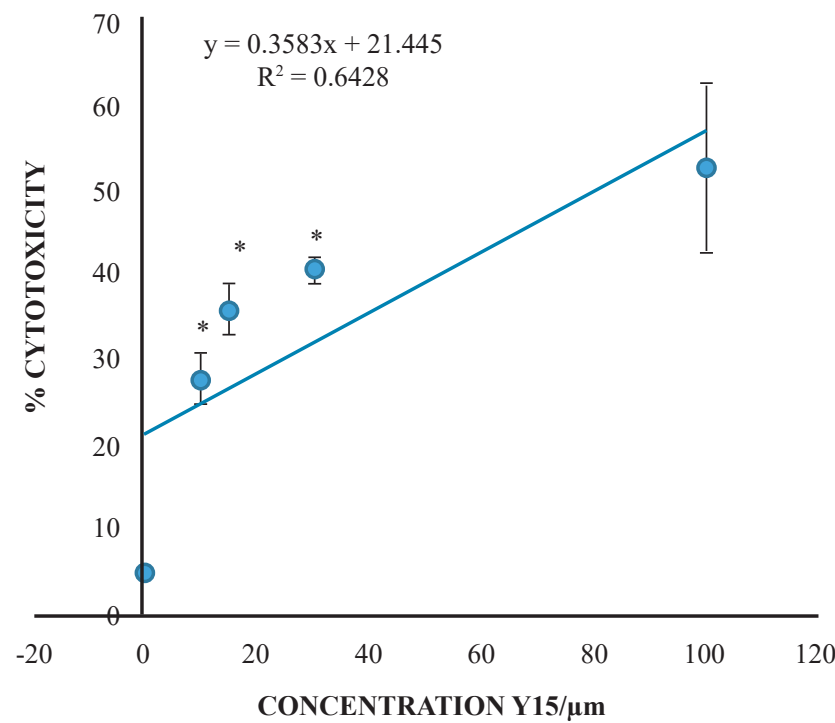

Fig. 1b: OVCAR-3 cells were incubated with Y15 $(10 \mu \mathrm{M}, 15 \mu \mathrm{M}, 30$ $\mu \mathrm{M}, 100 \mu \mathrm{M})$ for 24 -hour. Data is presented as the mean \pm SEM from triplicate experiments. Y15 produced a significant and dose dependent reduction in cell viability with IC50 value of $80 \mu \mathrm{M}$. Asterisks represent values significantly different from media controls $* p=0.01$

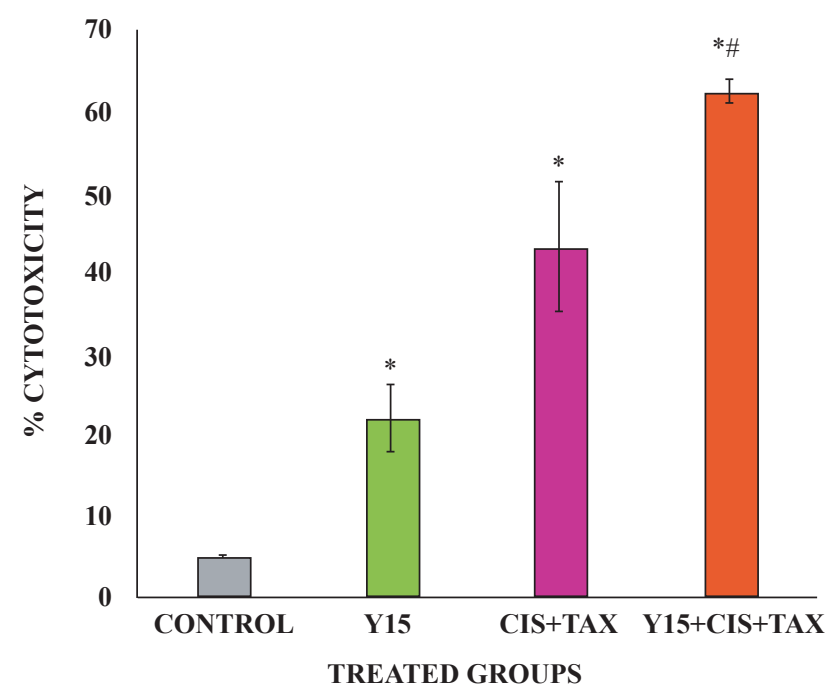

Fig. 2b: Cytotoxic effect of Y15 $(80 \mu \mathrm{M})$, cisplatin $(26 \mu \mathrm{M})$ paclitaxel $(1.5$ $\mathrm{nM}$ ) in OVCAR-3 cells with control sample at 24 hours. Data are representative of trials performed in triplicate \pm SEM. Asterisks (*) represent $p=0.05$ compared to the control group and number sign (\#) represents $p<0.05$ as compared to cisplatin plus paclitaxel. 
to the treatments, as inter- nucleosomal cleavage of cellular DNA by endonucleases is indicative of apoptotic cell death. VES only, VES plus Y15, VES plus cisplatin plus paclitaxel, Y15 plus cisplatin plus paclitaxel and cisplatin plus paclitaxel, all induced distinct DNA fragmentation patterns in contrast to vehicle treated cells that showed no fragmented DNA (Fig 3). Y15 induced no fragmentation.

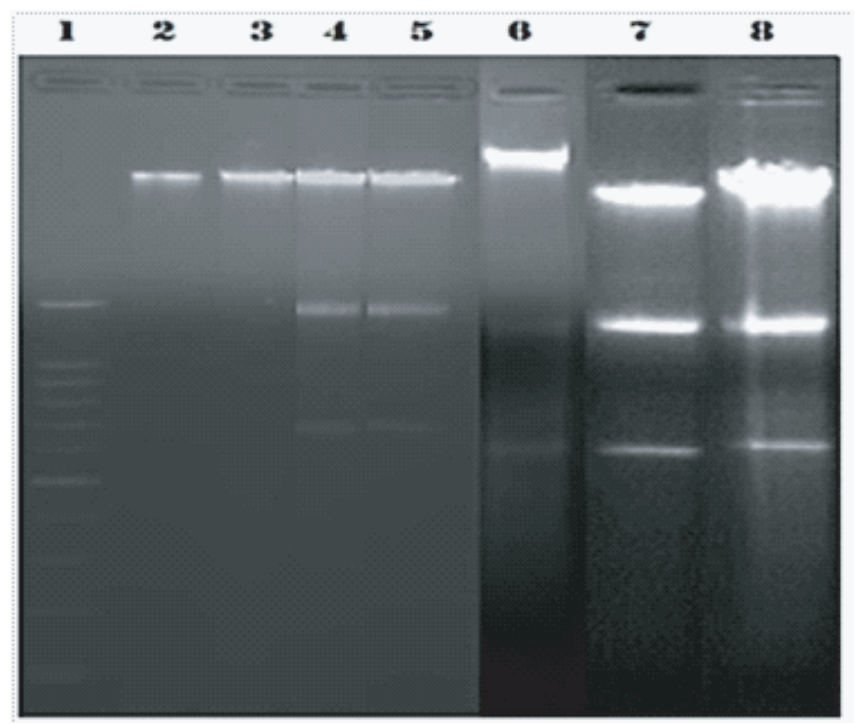

Fig. 3: Agarose gel (1.5\%) electrophoresis depicting DNA fragmentation patterns in OVCAR-3 cells after 24 hour exposure to different treatments. From left to right: lane 1, 100 bp marker; lane 2, dmso control; lane 3, Y15; lane 4, vitamin E succinate plus Y15; lane 5, vitamin E succinate plus cisplatin plus paclitaxel; lane 6, vitamin E succinate; lane 7, Y15 plus cisplatin plus paclitaxel; lane 8, cisplatin plus paclitaxel. DNA pattern was visualized using a UVP image analyser.

\section{DISCUSSION}

Patients with ovarian cancer are routinely treated with cisplatin and paclitaxel but response rates remain inadequate due to the development of drug-resistance. Therefore, effective combination therapies that are able to overcome resistance and improve patient outcome are highly desirable for patient survival. In the present study, the cytotoxic efficacy of VES or the FAK inhibitor (Y15) in combination with cisplatin and paclitaxel was validated in platinum-resistant OVCAR-3 ovarian cancer cells.

We initially examined the cytotoxic effects of VES and Y15 only using the Trypan blue assay. We found that both VES and Y15 exhibited significant cytotoxicity in OVCAR-3 cells in a dose dependent manner with an IC50 value of $250 \mu \mathrm{M}$ and $80 \mu \mathrm{M}$, respectively. This study is the first to demonstrate this profile of cytotoxicity in the OVCAR-3 cell line.
To investigate the mechanism of cell death involved in VES and Y15 treated cells, apoptosis was assessed by evaluating DNA fragmentations. Apoptosis is characterized biochemically by the production of 180-200 bp internucleosomal DNA fragments resulting from the activation of endonucleases. This produces a characteristic 'DNA ladder pattern' that can be visualized by agarose gel electrophoresis. The results confirmed DNA fragments in all treated groups except Y15. While their study is the first to report VES induced apoptosis in the OVCAR-3 cell line, previous studies have confirmed VES induced apoptosis in other types of cancers such as gastric (13), prostate (14) and neuroblastomas (15). Our finding of cisplatin and paclitaxel induced apoptosis is well-established in the literature (16). While Y15 induced significant cytotoxicity, the absence of DNA fragmentation in OVCAR-3 cells treated with Y15 confirms the involvement of non-apoptotic mediated death pathways. Y15 is a novel FAK inhibitor that works by binding the Y397 site on FAK resulting in inhibition of its catalytic activity (3). A similar Y397 inhibitor, TAE226 was also found to inhibit ovarian cancer cell growth while showing no significant apoptosis and implicating inhibition of insulin-like growth factor-I receptor (IGF-IR) in its cytotoxic mechanism (17).

For combination treatments, VES and Y15 both increased the cytotoxic activity of cisplatin plus paclitaxel in the OVCAR-3 cells. Cisplatin resistance in OVCAR-3 cells has been linked to over-expression of focal adhesion kinase [FAK] (18). Therefore, we suggest that Y15 increased sensitivity of OVACR-3 cells to cisplatin plus paclitaxel through its inhibition of FAK activity. Vitamin E succinate also clearly potentiated the effects of cisplatin plus paclitaxel. Previous work by Luo et al (19) evaluated the combined effect of cisplatin and VES in the OVCAR-3 cell line and noted that VES significantly increased sensitization of the OVCAR-3 cells to cisplatin primarily through its actions on multidrug resistant proteins. It is therefore, possible that this mechanism could also underlie the response being seen with the VES plus cisplatin plus paclitaxel combination in the study.

We also treated OVCAR-3 cells with a combination of VES plus Y15 and the study is the first to report a cytotoxic effect for this treatment in platinum-resistant ovarian cancer cells. Additionally, this cytotoxic effect was of comparable potency to the cisplatin plus paclitaxel combination and suggests the potential application of these two agents in this type of cancer. 


\section{CONCLUSION}

In conclusion, the data gathered in this study presents significant evidence to confirm the cytotoxic efficacy of VES and Y15 in OVCAR-3 cells and their potential to enhance sensitivity to cisplatin and paclitaxel in platinum-resistant ovarian cancer. This suggests a potential use in ovarian cancer therapy which will be further explored by our research group.

\section{ACKNOWLEDGEMENTS}

The authors would like to acknowledge the Rumbaugh Goodwin Institute at Nova South-eastern University for assisting with the completion of this study. We would also like to acknowledge the Research and Publications section at UWI Mona for providing funding for this project.

\section{REFERENCES}

1. Lowe KA, Chia VM, Taylor A, O'Malley C, Kelsh M, Mohamed M et al. An international assessment of ovarian cancer incidence and mortality. $\mathrm{J}$ Gynecol Oncol 2013; 130: 107-14.

2. Romero I, Bast Jr RC. Minireview: human ovarian cancer: biology, current management and path to personalizing therapy. Endocrinol 2012; 153: $1592-1602$.

3. Golubovskaya VM, Nyberg C, Zheng M, Kweh F, Magis A, Ostrov D et al. A small molecule inhibitor 1,2,4,5-Benzenetetraamine tetrahydrochloride, targeting the Y397 site of focal adhesion kinase decreases tumor growth. J Med Chem 2008; 51: 7405-16.

4. Hao HF, Naomoto Y, Bao XH, Watanabe N, Sakurama K, Noma K et al. Progress in researches about focal adhesion kinase in gastrointestinal tract. World J Gastroentero 2009; 15: 5916-23.

5. Sood AK, Coffin JE, Schneider GB, Fletcher MS, DeYoung BR, Gruman LM et al. Biological significance of focal adhesion kinase in ovarian cancer. Am J Pathol 2004; 165: 1087-95.

6. Annunziata CM, Kohn EC. Novel facts about FAK: new connections to drug resistance. J Natl Cancer Inst 2013; 105: 1430-1.
7. Halder J, Landen CN Jr, Lutgendorf SK, Li Y, Jennings NB, Fan D et al. Focal adhesion kinase silencing augments docetaxel-mediated apoptosis in ovarian cancer cells. Clin Cancer Res 2005; 11 (24 Pt 1): 8829-36.

8. Kline K, Yu W, Sanders BG. Vitamin E and breast cancer. J Nutr 2004; 134: 3458 S-3462S.

9. Anderson K, Simmons-Menchaca M, Lawson KA. Differential response of human ovarian cancer cells to induction of apoptosis by Vitamin E Succinate and Vitamin E analogue, alpha-TEA. Cancer Res 2004; 64: 4263-69.

10. Patacsil D, Osayi S, Tran AT, Saenz F, Yimer L, Shajahan A et al. Vitamin E succinate inhibits survivin and induces apoptosis in pancreatic cancer cells. Genes Nutr 2012; 7: 83-9.

11. Bermudez Y, Ahmadi S, Lowell NE, Kruk PA. Vitamin E suppresses telomerase activity in ovarian cancer cells. Cancer Detect Prev 2007; 31: 119-28.

12. Dunn KB, Heffler M, Golubovskaya V. Evolving therapies and FAK inhibitors for the treatment of cancer. Anticancer agents Med Chem 2010; 10: 722-734.

13. Wu K, Li Y, Zhao Y, Shan YJ, Xia W, Xia W et al. Roles of Fas signaling pathway in vitamin E succinate-induced apoptosis in human gastric cancer SGC-7901 cells. World J Gastroenterol 2002; 8: 982-86.

14. Israel K, Yu W, Sanders BG, Kline K. Vitamin E susccinate induces apoptosis in human prostate cancer cells: role of Fas in Vitamin E succinate triggered apoptosis. Nutr Cancer 2000; 36: 90-100.

15. Swettenham E, Witting PK, Salvatore BA, Neuzil J. Alpha tocopheryl succinate selectively induces apoptosis in neuroblastoma cells: potential therapy of malignancies of the nervous system? J Neurochem 2005; 94: $1448-56$.

16. Gibb RK, Taylor DD, Wan T, O'Connor DM, Doering DL, GercelTaylor C. Apoptosis as a measure of chemosensitivity to cisplatin and taxol therapy in ovarian cancer cell lines. Gyneocol Oncol 1997; 65: 13-22.

17. Halder J, Lin YG, Merritt W, Spannuth W, Nick A, Honda T et al. Therapeutic efficacy of novel focal adhesion kinase inhibitor TAE226 in ovarian carcinoma. Cancer Res 2007; 67: 10967-83.

18. Halder J, Kamat A, Landen-Jr C, Han L, Latgendof K, Lin Y et al. Focal adhesion kinase targeting using in vivo short interfering RNA delivery in neutral liposomes for ovarian carcinoma therapy. Clin Cancer Res 2006; 12: 4916-24.

19. Luo H, Daddysman MK, Jiang BH, Chen Y. Kaempferol enhances cisplatin's effect on ovarian cancer cells yhough promoting apoptosis caused by down regulation of cMyc. Cancer Cell Int 2010; 16. 